\title{
Kekerasan Berbasis Gender: Belenggu Patriarki Terhadap Perempuan Dalam Novel Tempurung Karya Oka Rusmini
}

\author{
Zahratul Umniyyah \\ Jurusan Sastra Indonesia Fakultas Ilmu Budaya (Universitas J ember) \\ Zahraniya333@gmail.com
}

\begin{abstract}
Violence against women still often occurs in societies adhering to a patriarchal system. The patriarchal system gives many disadvantages to women whose rights are shackled. The purpose of this study is to describe the lives of female figures who are victims of physical and psychological violence due to men and women who adhere to a patriarchal system. The results of this study indicate that violence against women is committed by both men and women. This violence has deeply traumatized female figures.
\end{abstract}

Keywords: radical feminism; violence; patriarchy; women.

\section{Pendahuluan}

Patriarki merupakan suatu sistem dominasi dan superioritas laki-laki, sistem kontrol terhadap penguasaan laki-laki kepada perempuan. Dalam patriarki melekat ideologi yang menyatakan bahwa laki-laki lebih tinggi dari perempuan, bahwa perempuan harus dikontrol oleh laki-laki dan perempuan adalah bagian dari milik laki-laki. ${ }^{1}$ Posisi perempuan di Bali tidak bisa dilepaskan dari konstruksi sosial dan budaya yang tumbuh subur di Bali yang didominasi sistem patrilineal dan memberikan keterbatasan kepada perempuan dalam bidang apa pun. Feminisme radikal mencangkup prespektif radikal-kultural dan feminis radikal-libertarian. Mencapai kesetaraan hak bagi perempuan adalah tujuan utama para reformis ini, dan dogma fundamental filsafat politik liberal yang sesuai bagi mereka. Tidak seorang pun feminis yang ingin mempertahankan status quo, terutama sistem seks atau gender yang mereka identifikasi sebagai penyebab utama opresi terhadap perempuan. Untuk dapat dikualifikasikan sebagai seorang feminis radikal, seorang feminis harus yakin bahwa sistem seks atau gender adalah penyebab fundamental dari opersi terhadap perempuan. Aliran ini berfokus pada seks, gender, dan reproduksi sebagai lokus bagi perkembangan feminis. ${ }^{2}$ Baik feminisme radikal-libertarian maupun radikalkultural menegaskan bahwa kita perlu menelaah hak dan tanggungjawab seksual serta reproduksi laki-laki dan perempuan, untuk dapat memahami secara penuh keberadaan sistem yang mendukung dominasi laki-laki dan subordinasi

1 Sugihastuti;, "Gender \& Inferioritas Perempuan

: praktik kritik sastra fem

(Pustaka Pelajar, 2007), 93, yogyakarta,

http:// library.fip.uny.ac.id/ opac/index.php?p=show detail\&id=4003.

2 Feminist Thought: Pengantar Paling Komprehensif Kepada Arus Utama Pemikiran

Feminis | Perpustakaan FIS, 67-69, accessed J anuary 12, 2021,

//library.fis.uny.ac.id\%2Fopac\%2Findex.php\%3Fp\%3Dshow_detail\%26id\%3D1319. 
perempuan. Feminisme radikal-kultural mengklaim bahwa perempuan harus dibebaskan bukan saja dari beban reproduksi alamiah dan motherhood biologis, melainkan juga dari pembatasan atas apa yang disebut sebagai standar ganda seksual, yang memungkinkan laki-laki dan bukan perempuan untuk bereksperimen secara seksual.

Pengertian gender menurut Fakih (2001:71) adalah perbedaan perilaku (behavioral differences) antara laki-laki dan perempuan yang dikonstruksi secara sosial, yakni perbedaan yang bukan kodrat atau bukan ketentuan Tuhan melainkan diciptakan oleh manusia (laki-laki dan perempuan) melalui proses sosial dan kultural yang panjang. Bentuk-bentuk ketidakadilan gender, yaitu: marginalisasi atau proses pemiskinan ekonomi; subordinasi atau anggapan tidak penting dalam keputusan politik; pembentukan stereotip atau melalui pelabelan negatif; kekerasan (violence); beban kerja lebih banyak dan lebih panjang. 3 Gender dan marginalisasi perempuan merupakan proses marginalisasi yang mengakibatkan kemiskinan yang banyak terjadi dalam masyarakat dan negara yang menimpa kaum laki-laki dan perempuan. Ada salah satu bentuk pemiskinan atas satu jenis kelamin tertentu dalam hal ini adalah perempuan yang disebabkan oleh gender. Dari segi sumbernya berasal dari kebijakan pemerintah, keyakinan, tafsiran agama, keyakinan tradisi dan kebiasaan atau bahkan asumsi ilmu pengetahuan. Marginalisasi kaum perempuan tidak saja terjadi di tempat pekerjaan, hal ini juga terjadi dalam rumah tangga, masyarakat atau kultur dan bahkan negara. Marginalisasi terhadap perempuan sudah terjadi sejak di rumah tangga dalam bentuk diskriminasi atas anggota keluarga yang laki-laki dan perempuan. Marginalisasi juga diperkuat oleh adat istiadat maupun tafsir

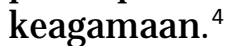

Gender dan subordinasi merupakan suatu pandangan gender yang dapat menimbulkan subordinasi terhadap perempuan. Anggapan bahwa perempuan itu irrasional atau emosional sehingga perempuan tidak bisa tampil memimpin sehingga mengakibatkan munculnya sikap yang menempatkan perempuan pada posisi yang tidak penting. Dalam rumah tangga masih sering terdengar jika keuangan keluarga sangat terbatas, dan harus mengambil keputusan untuk menyekolahkan anaknya, maka anak laki-laki akan mendapatkan prioritas utama.5 Gender dan stereotip secara umum memandang stereotip adalah pelabelan atau penandaan terhadap suatu kelompok tertentu. Stereotip selalu merugikan dan menimbulkan ketidakadilan. Salah satu jenis stereotip bersumber dari pandangan gender. Masyarakat memiliki anggapan bahwa tugas utama kaum perempuan adalah melayani suami. Stereotip ini berakibat wajar sekali jika pendidikan kaum perempuan dinomorduakan. Banyak peraturan pemerintah, aturan keagamaan, kultur dan kebiasaan masyarakat yang dikembangkan karena stereotip tersebut.

Novel Tempurung karya Oka Rusmini mengangkat masalah sosial terutama masalah keperempuanan dan beberapa konflik yang terjadi dalam masyarakat dan pemberontakan perempuan Bali dalam memprotes adat-istiadat dan budayanya. Perjuangan perempuan untuk mendapatkan hak-haknya sebagai manusia merupakan perjuangan yang tidak pernah berhenti karena berbagai hal dapat terjadi dalam perkembangan peradaban yang sangat pesat ini. Hal ini

\footnotetext{
3 Fakih Mansour, Analisis Gender Dan Transformasi Sosial (Yogyakarta: Pustaka Pelajar, 2001), 12- 13.

4 Mansour, 13- 15.

5 Mansour, 15- 16.
} 
berkaitan erat dengan nilai tradisional dan budaya yang dikuasai oleh kaum lakilaki yang disebut dengan budaya patriarki. Salah satu daerah di Indonesia yang selalu menjunjung tinggi adat istiadat dan budaya adalah Bali. Di dalam novel ini dipaparkan suatu keadaan para perempuan yang terbelenggu adanya sistem patriarki. Patriarki merupakan hal yang tidak pernah surut untuk dibahas karena dianggap sangat merugikan perempuan. Patriarki adalah sebuah sistem yang berpusat pada garis laki-laki, di dalam novel Tempurung dipaparkan bahwa garis ayah memiliki peranan utama dalam memberikan batas gerak terhadap perempuan.

\section{Belenggu Perempuan Karena Sistem Patriarki}

Gender dan kekerasan mendeskripsikan bahwa kekerasan (violence) adalah serangan atau invansi (assault) terhadap fisik maupun integritas mental psikologis seseorang. Kekerasan terhadap sesama manusia pada dasarnya berasal dari berbagai sumber, namun salah satu kekerasan terhadap satu jenis kelamin tertentu yang disebabkan oleh anggapan gender yang disebut gender-related violence. Kekerasan gender disebabkan oleh ketidaksetaraan kekuatan yang ada dalam masyarakat. Bentuk-bentuk kejahatan yang dikategorikan sebagai kekerasan gender adalah: (1) bentuk pemerkosaan terhadap perempuan, termasuk pemerkosaan dalam perkawinan; (2) tindakan pemukulan dan serangan fisik yang terjadi dalam rumah tangga (domestic violence). Termasuk tindakan dalam bentuk penyiksaan terhadap anak-anak (child abuse); (3) bentuk penyiksaan yang mengarah pada organ alat kelamin (genital mutilation), seperti penyunatan terhadap anak perempuan. Alasan dari penyunatan ini adalah untuk mengontrol kaum perempuan; (4) kekerasan dalam bentuk pelacuran (prostitution). Pelacuran merupakan bentuk kekerasan terhadap perempuan yang diselenggarakan oleh suatu mekanisme ekonomi yang merugikan kaum perempuan, contohnya: (1) kekerasan dalam bentuk pornografi. J enis kekerasan ini termasuk kekerasan nonfisik, yakni pelecehan terhadap kaum perempuan yang menjadikan tubuh perempuan sebagi objek untuk keuntungan seseorang; (2) kekerasan dalam bentuk pemaksaan sterilisasi dalam keluarga berencana (enforced sterilization); (3) kekerasan terselubung (molestation), yakni memegang atau menyentuh bagian tertentu dati tubuh perempuan dengan berbagai cara dan tanpa kerelaan si pemilik tubuh; (4) pelecehan seksual (sexual and emotional rassment). ${ }^{6}$

Perempuan yang terbelenggu menyuarakan kisahnya dan kisah ibunya yang menjadi korban dari sistem patriarki, perempuan tersebut adalah Luh Sipleg. Di dalam keluarga Luh Sipleg masih berpedoman dengan sistem patriarki sehingga memberikan kerugian besar untuk Luh Sipleg. Luh Sipleg terbelenggu karena posisinya sebagai anak perempuan dianggap tidak berharga sehingga dijual, sedangkan Ni Luh Songi terbelenggu karena ambisi suaminya untuk mendapatkan bayi laki-laki. Dua perempuan ini adalah korban dari sistem patriarki yang diterapkan oleh suaminya, I Wayan Sager. Pada novel Tempurung, terdapat sebuah subjudul Sepotong Ternak: Meme. ${ }^{7}$ Luh Sipleg menceritakan masa lalu Ni Luh Songi (ibunya). Songi tidak dapat melahirkan anak lelaki, semua anak yang dilahirkannya adalah perempuan. I Wayan Sager, suaminya, menganggap semua kesialan yang terjadi kepadanya disebabkan Songi tidak

${ }_{6}$ Mansour, 15- 16.

7 Oka Rusmini, Tempurung (J akarta: PT. Gramedia Widiasarana Indonesia, 2010), 102. 
dapat melahirkan anak laki-laki. Kehadiran anak laki-laki dianggap sangat penting karena hanya anak laki-laki yang dapat melanjutkan keturunan.

Kata Bapak, perempuan yang tidak bisa melahirkan bayi lelaki, perempuan sial! Hidup tanpa keturunan lelaki kiamat! Hidup itu sudah mati tanpa lelaki! Dan, si tolol itu percaya. Sipleg tidak bisa menghitung berapa puluh bayi yang dilahirkan mati! Hanya untuk mendapatkan bayi lelaki, perempuan itu membiarkan tubuhnya dititipi daging terus menerus. Daging yang memakan isi tubuhnya. Sering Sipleg berpikir, mungkinkah daging-daging yang tumbuh di perut ibunyamemakan isi otaknya?8

Hal tersebut membuat Songi mengalami penderitaan. Demi mengikuti ambisi suaminya, Songi terus-menerus hamil sampai rahimnya mengalami kerusakan dan dinyatakan tidak dapat hamil lagi. Dalam hal ini perempuan sangat dirugikan. Perempuan yang seharusnya merasakan kebahagiaan dalam pernikahan harus merelakan kehilangan rahimnya karena terlalu patuh kepada suaminya. Sebagai suami yang penuntut dan tidak pernah menafkahi istri, Sager dianggap sebagai laki-laki yang tidak bertanggung jawab, sedangkan kepatuhan Songi kepada suaminya justru harus dibayar mahal dengan kerusakan rahimnya. Sesuai dengan subjudulnya, Sepotong Ternak: Meme, dalam bagian ini dipaparkan bawa Sipleg mengibaratkan ibunya seperti ternak, yang terusmenerus beranak demi memenuhi ambisi suaminya. Kekerasan gender pada bagian ini disebabkan oleh ketidaksetaraan kekuatan yang ada dalam masyarakat. Tanpa disadari, telah terjadi bentuk kejahatan yang dikategorikan sebagai kekerasan gender yaitu pemerkosaan terhadap perempuan, termasuk pemerkosaan dalam perkawinan. Songi menjadi korban kekerasan dalam perkawinan karena harus melayani suaminya yang menuntut kehamilan anak laki-laki.

Seorang ibu rumah tangga mempunyai peran yang paling penting untuk menciptakan pola hidup sehat yang bisa menghindarkan semua penghuni rumah dari berbagai jenis ancaman penyakit. Salah satu bentuk tanggung jawab yang harus dipikul oleh ibu rumah tangga untuk menjaga kesehatan keluarga adalah setiap hari harus selalu membuat dan menyediakan makanan yang sehat, bergizi dan tetap enak untuk dinikmati serta sesuai dengan standar dari pola hidup sehat. Karena lebih sering tinggal di rumah, ibu rumah tangga juga berkewajiban untuk menjaga kebersihan lingkungan tempat tinggal demi kesehatan keluarganya. Selain membuat makanan, tugas lain ibu rumah tangga untuk menjaga kesehatan keluarga adalah memberi pendidikan untuk anak sejak usia belia agar dapat mengatur pola hidup sehat dalam menjalani kegiatan mereka setiap hari. Peran seperti itu tidak dijalankan oleh Ni Luh Songi. Ni Luh Songi tidak pernah memperhatikan kesehatan anak-anak perempuannya karena sibuk mewujudkan ambisi suaminya untuk mendapatkan anak laki-laki.

Banyak daging yang tumbuh dalam perut Ibu mati. Perempuan itu memang tak punya jiwa. Dia masih terus membiarkan tubuhnya ditumbuhi daging. Tak pernah peduli anak-anaknya yang lain. Usia adik-adiknya tidak sampai lima tahun, mereka mati satu demi satu. Ibu tetap tidak peduli. ${ }^{9}$

8 Rusmini, 88.

9 Rusmini, 104. 
Kehadiran anak laki-laki membuat kehidupan Ni Luh Songi menjadi terbelenggu. Songi dihadapkan dengan pernyataan suaminya bahwa hanyalah anak laki-laki yang dapat meneruskan keturunan. Hal tersebut membuktikan bahwa sistem patrilineal masih tumbuh subur di Bali. Garis keturunan laki-laki masih dianggap penting sehingga anak perempuan dikesampingkan. Ambisi memiliki anak laki-laki menyebabkan Songi harus tunduk dengan aturan adat yang menganggap anak lelaki memiliki peran penting dibandingkan anak perempuan. Songi terus-menerus hamil tanpa memperhatikan kondisi kesehatannya sehingga rahimnya menjadi rusak. Hal tersebut membuktikan bahwa sistem patriarki dapat membelenggu posisi perempuan sehingga perempuan tetap menjadi pihak yang dirugikan, dalam hal ini Songi menjadi sangat rugi karena harus kehilangan rahimnya. Selain Songi, anak-anak perempuan Songi (salah satunya adalah Luh Sipleg) mengalami kerugian karena tidak mendapatkan kasih sayang dari seorang ibu yang selalu sibuk dengan kehamilannya.

Perempuan itu anehnya tidak pernah berpikir, semua makhluk kecil di rumah ini perlu makan. Benar-benar makhluk perempuan yang membuat Sipleg bingung. Manusia-manusia yang dia muntahkan dari tubuhnya rata-rata kurang gizi. Prematur. Dan ibunya tidak pernah bias mengeluarkan ASI untuk adik-adiknya. Adik-adiknya tumbub dari air tajin, beras yang ditanak, airnya diminumkan ke adik-adiknya. Makanya tak ada yang bisa bertahan. Sipleg pun akhirnya biasa dengan aroma kematian. ${ }^{10}$

Anak-anak perempuan Songi menjadi pihak yang terbelenggu karena tidak pernah mendapatkan haknya sebagai anak perempuan. Kekerasan berbasis gender pun terjadi kepada Songi dan adik-adiknya. Kekerasan berupa serangan fisik yang terjadi dalam rumah tangga (domestic violence), termasuk tindakan dalam bentuk penyiksaan terhadap anak-anak (child abuse), dalam hal ini, penyiksaan dilakukan terhadap anak-anak dengan cara tidak memberikan asupan gizi yang cukup terhadap bayi prematur. Tidak diberikan asi dan kelayakan terhadap bayi prematur merupakan wujud kekerasan yang dilakukan seorang ibu kepada anak perempuannya. Hal tersebut disebabkan oleh anggapan bahwa anak perempuan bukanlah hal yang patut diperhitungkan, hanyalah anak laki-laki yang berharga di dalam sebuah keluarga, sehingga Songi dan Sager berambisi untuk mendapatkan anak laki-laki. Anak perempuan menjadi korban dan mengalami kerugian besar dengan adanya penerapan system patriarki. Gender dan beban kerja beranggapan bahwa kaum perempuan memiliki sifat memelihara dan rajin, serta tidak cocok untuk menjadi kepala rumah tangga. Akibatnya semua pekerjaan domestik rumah tangga menjadi tanggung jawab kaum perempuan. Bias gender mengakibatkan beban kerja tersebut seringkali diperkuat dan disebabkan oleh adanya pandangan atau keyakinan di masyarakat bahwa pekerjaan yang dianggap masyarakat sebagai jenis "pekerjaan perempuan", seperti semua pekerjaan domestik, dianggap dan dinilai lebih rendah dibandingkan dengan jenis pekerjaan yang diangap sebagai "pekerjaan laki-laki", serta dikategorikan sebagai "bukan produktif" sehingga tidak diperhitungkan dalam statistik ekonomi negara.

10 Rusmini, 105. 
Ketika perempuan mengalami kehamilan dan melahirkan, rahim akan mengalami perubahan. Rahim mengalami luka karena perubahan tersebut sehingga rahim membutuhkan waktu untuk proses penyembuhan dan pengembalian seperti kondisi semula. Kehamilan yang ideal berjarak dua tahun karena dua tahun dapat memberikan waktu untuk kesembuhan rahim. Kehamilan dengan jarak yang dekat yang terjadi berulang-ulang seperti yang dialami Songi memberikan dampak buruk pada rahimnya. Kerusakan yang dialami rahim Songi memberikan dampak buruk yaitu Songi tidak dapat hamil lagi. Kesuburan yang dulu digunakan Songi untuk memenuhi keinginan suaminya dalam mengikuti tradisi patriarki, kini harus hilang karena ambisi tersebut. Bidang-bidang kehidupan perempuan yang normalnya berada di bawah kontrol patriarki. Pertama, daya produktif atau tenaga kerja perempuan. Lakilaki mengontrol produktivitas perempuan di dalam maupun di luar urusan rumah tangga. Kedua, laki-laki juga mengontrol daya reproduktif perempuan. Banyak kasus dalam masyarakat, perempuan tidak memiliki kebebasan dalam menentukan jumlah anak yang diinginkan, dan waktu untuk melahirkan anak. Ketiga, kontrol laki-laki juga berlaku atas seksualitas perempuan. Perempuan diharuskan memberikan pelayanan seksual kepada laki-laki sesuai dengan keinginan dan kebutuhan pihak laki-laki. Keempat, gerak perempuan dikontrol untuk mengendalikan seksualitas, produksi, dan reproduksi mereka. Kelima, laki-laki juga mengontrol harta milik dan sumber daya ekonomi lain dengan jalan sistem pewarisan dari laki-laki ke laki-laki (Bahsin dalam Sugihastuti dan Saptiawan, 2007:94). Ni Luh Songi dianggap sebagai perempuan yang terbelenggu karena sistem patrairki karena tidak memiliki hak untuk mengontrol daya reproduktifnya.

Sebagai kerangka untuk menampung pemikiran gender di dalam novel, pandangan Helene Cixous mengenai bahasa perempuan dan gagasannya mengenai tulisan perempuan atau bahasa yang menentang pemikiran laki-laki yang bersifat mesogini dapat mengeksplorasi isu-isu mengenai perempuan dalam novel Tempurung. Menurut Cixous, penulisan tubuh ke dalam teks dapat memberikan keleluasaan untuk bergerak dan menciptakan teks perempuan dengan bahasa yang bebas. Tempurung menyajikan cerita tentang tubuh perempuan yang sesungguhnya tidak hanya menjadi milik mereka sendiri bahkan para perempuan sering merasa bingung ketika berhadapan dengan tubuh mereka sendiri karena mereka tidak terlalu mengenal tubuhnya. Beberapa perempuan pun sering mempertanyakan keberadaannya karena mereka tidak memahami apakah menjadi perempuan itu anugerah atau kutukan. Perempuan tersebut sering merasa tidak nyaman dengan tubuh mereka sendiri yaitu ketika mengalami masa kehamilan dan merasakan kesakitan yang luar biasa karena organ reproduksinya, sedangkan pihak laki-laki hanya dapat menuntut mereka untuk memiliki anak, terutama anak laki-laki.

Luh Sipleg mengisahkan masa lalunya, ketika berusia 16 tahun, Luh Sipleg dijual oleh orang tuanya demi membayar hutang orang tuanya. Hal tersebut disebabkan karena orang tua Luh Sipleg menganggap anak perempuan tidak penting dan tidak perlu dipertahankan.

Hanya lelaki yang bisa melanjutkan keturunan. Memuja leluhur. Meneruskan garis keluarga. Makanya, perempuan kumuh dan kurus itu tega menjual Sipleg ke Payuk. Tanpa hati, karena perempuan dekil itu memang tidak punya hati. ${ }^{11}$

\section{Rusmini, 104.}


Kemiskinan telah membuat Luh Sipleg tidak mempunyai pilihan dalam kehidupannya. Peristiwa penjualan Luh Sipleg kepada Ni Ketut Jinah mengharuskan Luh Sipleg menikah dengan I Wayan Payuk dan tidak pernah merasakan kebahagiaan karena kehilangan haknya sebagai perempuan. Walaupun I Wayan Payuk adalah lelaki yang baik, Luh Sipleg tetap merasa tidak bahagia karena Luh Sipleg merasa terikat dengan hutang orang tuanya dan Luh Sipleg berperan sebagai alat pembayaran hutang. Luh Sipleg menjelma menjadi perempuan pendiam, bahkan mertuanya menganggapnya perempuan tuna wicara. Luh Sipleg tidak pernah berbicara dengan mertuanya, tidak pernah menjawab semua pertanyaan dari mertuanya, selalu diam dan tidak pernah mempedulikan mertuanya. Luh Sipleg menyimpan dendam untuk orang-orang yang berkaitan dengan penjualan dirinya, yaitu orang tuanya sebagai penjual dan mertuanya sebagai pembeli.

Kekerasan dalam bentuk pelacuran (prostitution yang diselenggarakan oleh suatu mekanisme ekonomi dapat merugikan kaum perempuan. Kondisi yang dialami Sipleg merupakan kekerasan dalam bentuk pornografi. J enis kekerasan ini termasuk kekerasan nonfisik, yakni pelecehan terhadap kaum perempuan yang menjadikan tubuh perempuan sebagai objek untuk keuntungan seseorang. Peristiwa penjualan Luh Sipleg menempatkannya di wilayah yang sangat tidak nyaman dan tidak kondusif bagi kehidupannya. Luh Sipleg berada di dalam kondisi terbelenggu akibat perbuatan orang tuanya sehingga Luh Sipleg merasa tidak pernah mendapatkan kebahagiaan sepanjang berada di dalam kondisi tersebut. Luh Sipleg tidak mendapatkan haknya sebagai perempuan yang bebas sejak sebelum menikah dan setelah menikah sehingga Luh Sipleg berada di dalam kondisi yang tidak memberikan kenyamanan bagi hidupnya. Dalam hal ini, Luh Sipleg adalah korban dari penerapan sistem patriarki, dengan anggapan posisi anak perempuan tidak berharga, maka anak perempuan dijual untuk membayar hutang. Kekerasan terhadap anak perempuan memberikan efek jangka panjang terhadap anak. Luh Sipleg yang seharusnya mendapatkan rasa aman dari kedua orang tuanya, justru mendapatkan perlakuan dan pengalaman buruk dari kedua orang tuanya. Hal tersebut membuat luh Sipleg menjadi tidak percaya diri dan tidak mudah mempercayai orang lain. Kekerasan terhadap perempuan adalah tindakan yang melanggar hak-hak perempuan. Sebagai seorang korban kekerasan, Sipleg mengalami trauma secara mendalam.

Kekerasan terhadap perempuan tidak hanya dilakukan oleh laki-laki, perempuan pun dapat melakukan kekerasan terhadap perempuan. Hal tersebut terjadi kepada Sipleg, kedua orang tuanya menjadi pelaku kekerasan terhadap Sipleg. Posisi perempuan masih dipandang rendah dan tidak berharga sehingga diperlakukan dengan semena-mena. Sipleg berusaha melakukan pemberontakan, tetapi ruang geraknya terbatas. Kekerasan yang dialami Sipleg sejak kecil menimbulkan kebencian yang mendalam terhadap laki-laki.

\section{Kesimpulan}

Tempurung berusaha mengungkapkan ketidakadilan akibat sistem patriarki yang telah mengakar kuat di dalam masyarakat. Tempurung pun secara dominan membahas masalah budaya Bali yang sangat kental dengan patriarki. Adanya pembedaan antarmanusia dapat menimbulkan berbagai ketidakadilan dalam masyarakat. Masyarakat yang memegang prinsip patriarki masih memandang rendah kedudukan perempuan. Kesetaraan gender dan 
persamaan hak yang seharusnya dimiliki perempuan, belum berlaku terhadap tokoh Sipleg dan Songi dalam novel Tempurung. Konsep patriarki masih tumbuh subur di Bali. Patriarki dapat menimbulkan kekerasan terhadap perempuan. Kekerasan terhadap perempuan tidak hanya dilakukan oleh laki-laki, perempuan pun dapat menjadi pelaku kekerasan. Penelitian ini diharapkan mampu menanamkan rasa mencintai dan menghargai perjuangan perempuan di setiap sisi dunia.

\section{Daftar Pustaka}

\section{Buku}

Mansour, Fakih. Analisis Gender Dan Transformasi Sosial. Yogyakarta: Pustaka Pelajar, 2001.

Rusmini, Oka. Tempurung. J akarta: PT. Gramedia Widiasarana Indonesia, 2010.

\section{Internet}

Feminist Thought: Pengantar Paling Komprehensif Kepada Arus Utama Pemikiran Feminis | Perpustakaan FIS. Accessed January 12, 2021. // library.fis.uny.ac.id\%2Fopac\%2Findex.php\%3Fp\%3Dshow_detail\%26i d\%3D1319.

Sugihastuti; "Gender \& Inferioritas Perempuan : praktik kritik sastra feminis." Text. Pustaka Pelajar, $2007 . \quad$ Yogyakarta. http:/ / library.fip.uny.ac.id/opac/ index.php?p=show_detail\&id=4003. 